\title{
Evaluation of global change impacts on diffuse pollution
}

\section{Gilles Pinay* and David M Hannah}

\author{
Address: School of Geography, Earth \& Environmental Sciences, University of Birmingham, Edgbaston, Birmingham, B15 2TT, UK \\ *Corresponding author: Gilles Pinay (g.pinay@bham.ac.uk) \\ FI000 Biology Reports 2009, I:82 (doi: 10.34I0/BI-82)
}

The electronic version of this article is the complete one and can be found at: http://FI000.com/Reports/Biology/content///82

\begin{abstract}
In a global change context, several recent advances in the field of hydrology and biogeochemistry suggest that a move from a riparian to a river drainage basin perspective is necessary to reframe research and thus provide a more integrated scientific understanding to inform water- and land-use management and policy. We explore this assertion using the control of diffuse pollution as an exemplar.
\end{abstract}

\section{Introduction and context}

Climate warming and concomitant socioeconomic change over the next few decades threaten to alter hydrological and physicochemical characteristics of water bodies (including rivers, lakes and wetlands) and so impact on water-dependent ecosystems [1,2]. Shifts in aquatic and riparian ecosystem structure and function are expected due to so-called 'unavoidable climate change', with potential for impacts to be either heightened by 'additive pressures' or mitigated by management at the local scale. Climate change may increase the frequency and magnitude of floods while drought and water scarcity may also become more severe [3]. Such shifts in extreme climate-driven events (similar to those experienced across Europe in the summer of 2003) have major consequences for water quantity and quality. Even the type and status of water bodies (wetland, ephemeral stream and so on) are intrinsic climatic functions, hence subject to variation under climate change. In the near future, modifications to global agricultural policy may be expected to influence decision making and land-use management practices within watersheds. These policy changes are likely to occur irrespective of climate change, which itself will create new challenges and opportunities for land and water resource managers. Indeed, the marked acceleration of the global nitrogen cycle measured today is the direct consequence of significant anthropogenic inputs (mostly chemical fertilizer application) over the last 60 years, which have led to a doubling of reactive nitrogen in terrestrial ecosystems
[4]. Moreover, the acceleration of the hydrological cycle due to climate change has resulted in a more rapid transfer of nitrogen through river drainage basins [5].

Since Hynes's seminal paper [6] on the importance of considering the river and its valley in context, there has been a growing understanding of the role of the drainage basin in river water quality. Yet, for a long time, dominant paradigms (notably, the river continuum concept [7] and the spiralling concept [8]) have stressed instream microbial processes as the main factors in recycling and removing energy and matter originating from the drainage basin. Meanwhile, Peterjohn and Correll [9] provided evidence for the role of riparian zones along streams in buffering nutrient input from upslope. In the past three decades, hundreds of studies have evaluated the capacity of these channel-marginal wetlands to retain and/or remove different pollutants [10]. A concerted research effort identified riparian zones as biogeochemical 'hot spots' [11], which can efficiently remove nitrogen by a microbial denitrification process in temperate, continental, or Mediterranean climates so long as the local hydrogeomorphology conditions facilitate transfer of upslope nitrate to anaerobic riparian sites [12]. However, several recent advances in this field stress that emphasis on the role of riparian and instream processes in the regulation of upslope diffuse pollution input has its limitations, especially in the context of climate change. Of particular note, we submit that a move from a fluvial hydrosystem to a river drainage 
basin perspective is necessary to reframe research and thus provide a more integrated scientific understanding to inform water- and land-use management and policy.

\section{Major recent advances}

Several recent findings (highlighted below) suggest that, when addressing the impact of global change on the controls on diffuse pollution, it would be most pertinent to move away from a classical impact assessment of climatic change on riparian zones and adopt a broader spatio-temporal perspective. Adopting a drainage basin approach to understanding the consequences of climate change on water quality would allow the research community to address the problem of intrinsic limitation of nutrient removal in landscape structures; to tackle the impact of land-use change on river flow; and to grasp the consequences of the interdependency of element cycles and the cumulative effect of the long-term human impact on river systems.

\section{Intrinsic limitations of nitrogen removal in riparian zones and instream}

In a recent field study in riparian zones of small Dutch streams, Hefting et al. [13] found that nitrogen buffering capacity decreased with nitrate load but that the rate of emission of nitrous oxide, a potent greenhouse gas, increased dramatically with nitrogen load.

At the drainage basin level, Montreuil and Merot [14] quantified the nitrogen removal capacity of valley bottom wetlands in 18 agricultural drainage basins ranging from 3 to $30 \mathrm{~km}^{2}$ in a temperate-oceanic climate. They determined that, on average, $11 \%$ of valley bottom wetlands within a drainage basin can reduce stream nitrate concentration by up to $30 \%$ at the outlet. They also estimated that a $5 \%$ increase in the area of the existing valley bottom wetlands can decrease nitrate concentration by another $30 \%$. Their results emphasise the importance of riparian wetlands as a powerful tool to reduce diffuse nitrogen pollution but also show that riparian zones cannot buffer the entire diffuse pollution load. In this context, a recent report on ${ }^{15} \mathrm{~N}$ addition to 72 streams across multiple biomes and land uses in the US showed that both total uptake velocity and denitrification uptake velocity (which account for the nitrogen removal in rivers) decreased with nitrate concentration [15]. This suggests that instream processes cannot cope with excess nutrient input. In another independent study, Brookshire et al. [16] developed a mechanistic model of instream cycling and transport of nitrogen and phosphorus and tested it on more than 140 stream reaches. They found that small streams tend toward no net increase or retention of nutrients, with removal and storage balancing input. Therefore, they suggest that the chemistry of small streams represented an integrated measure of terrestrial nutrient losses.

\section{Impact of land use on river flow}

Alterations of the spatial and temporal distributions of river flows and groundwater recharge are determined by changes in temperature (evapotranspiration) and precipitation (water balance) but modified by river basin properties (including land use). Climate is the first-order driver of river flow regimes, with the basin being a secondorder control [17]. Climate change impacts on hydrological processes may be identifiable already and further shifts in hydrological regime are predicted or anticipated [5]. Disaggregating climate from land-use controls on river flow is challenging, and although the matter is open to debate, the role of basin properties is considered insufficiently in many studies assessing river flow sensitivity to climate change. In an international water balance modelling study of 1,508 basins, long-term river flow was shown to be explained by land cover attributes [18]. Results indicate that land cover information makes a small but nonetheless significant contribution to model efficiency. However, research into 459 Austrian basins suggests that land use, soil type, and geology do not exert a major influence on runoff coefficients [19]. These different results can be reconciled if we consider that, with increasing spatial (basin area) and temporal (seasonal, annual, and beyond) scale, climate drivers override land-use influences on river flow [20].

\section{Impact of global change on carbon and nitrogen fluxes}

The recent widespread increase in concentration of dissolved organic carbon (DOC) in surface water in the Northern Hemisphere has been attributed to a consequence of a decline in the sulphate content of atmospheric deposition [21]. Using $\delta^{13} \mathrm{C}$ and $\delta^{14} \mathrm{C}$ analysis, Guo and Macdonald [22] demonstrate that, in large Arctic rivers, particulate organic carbon (POC) is derived from permafrost thawing and river bank erosion whereas DOC originates from modern terrestrial biomass. They infer that, during Arctic warming, an increase in DOC fluxes (caused by an increase in plant productivity following a shift from tundra to broadleaf plants) as well as an increase of POC fluxes (through melting of previously frozen soil horizons) can be expected. These results highlight the high interdependency between the carbon cycle and climate change, as well as the contribution of land-use change, as confirmed by Evans et al. [23] who demonstrated that relatively carbon-poor mineral soils under moderate to intensive grazing export DOC from older soil carbon. Similarly, there is clear evidence that vegetation and soils (and therefore land use) control the nutrient export from watersheds [24]. Landscape simplification and land-use intensification lead to diffuse 
pollution, which is often more focused than generally realised [25] because certain parts of basins generate disproportionate pollution risks and because hydrological disconnection along flowpaths means that, even where risks are generated, they do not necessarily connect with the drainage network. The consequence of this is that riparian zones are often bypassed by, or disconnected from, diffuse nutrient input from upslope [26]. In turn, this necessitates considering the possible evolution of the landscape as a whole under global change, the riparian zone being one landscape element among others.

\section{Interdependency of element cycles}

In a recent study of dissolved inorganic nitrogen retention transport through a headwater basin, Triska et al. [27] demonstrated that biologically active carbon controlled nitrate removal during both hillslope and riparian zone transport. This carbon control on nitrate removal operated via its role as an electron donor for microbial denitrification. A recent synthesis indicated that, of the 1.9 $\mathrm{Pg} \mathrm{C}$ per year delivered from land to river; half was consumed within the river systems before reaching the oceans [28]. This new evaluation stresses the importance of land-derived, biologically available carbon for heterotrophic microbial processes such as denitrification in river systems and the tight coupling of the nitrogen and carbon cycles [29].

\section{Long-term legacy of anthropogenic impact}

Walter and Merritts [30] demonstrated that recent historical human settlement has completely changed the geomorphology of a large part of the mid-Atlantic streams of the northeast coast of the USA but also the perception of what is, and was, a 'natural' stream. This result questions strongly the resilience capacity of streams and their riparian zones under climate change and the confidence to be given to restoration goals and the concept of reference sites in human-impacted areas.

\section{Future directions}

\section{Assessing ecosystem sensitivity to hydrological change}

Although aquatic ecosystem vulnerability to global change is recognised, knowledge of the most ecologically sensitive periods to hydrological events/extremes (for example, floods, droughts/low flows, and soil moisture deficit) and associated water stress and habitat disturbance [1] is limited. In addition to a focus on extremes, there is an evolving awareness of the importance of considering the spectrum of hydrological conditions experienced by habitats and their linkages to ecosystem structure and functioning. Long-term data sets have a crucial role to play in elucidating climate-hydrologyecology links and setting short-term variability in a wider context (for example, [31]).

\section{Uncertainty: reduction and management}

Numerous authors have called for research to reduce uncertainty over (a) how climate change may affect freshwaters and (b) how water- and land-use managers should mitigate and adapt to climate change [32]. Uncertainties in predicting impacts may be attributed to limitation of historical data (in terms of duration, spatial coverage, homogeneity and so on) for model parameterisation, calibration, and validation; incomplete knowledge of complex process nonlinearity and feedbacks; general circulation model (GCM) scenarios; downscaling of GCM data to basin scale; and hydrological models [33,34]. Improved characterisation of model uncertainty is necessary to better inform risk management approaches and water- and land-use managers' decision making [35].

\section{New ways}

Sutka et al. [36], using intramolecular distribution of nitrogen isotopes (isotopomer) in $\mathrm{N}_{2} \mathrm{O}$, measured significant differences in ${ }^{15} \mathrm{~N}$ site preference of $\mathrm{N}_{2} \mathrm{O}$ between nitrification and denitrification. This approach has the potential to decipher the respective role of these two processes in emitting this greenhouse gas in different ecosystems and their in situ driving factors. Clément et al. [37] were able to measure iron-driven denitrification in riparian wetland, allowing oxidation of ammonia under anaerobic conditions and further denitrification of the nitrate produced by denitrification. If this new pathway is confirmed to be widely occurring, it challenges the currently accepted belief that denitrification in riparian zones is limited by nitrate production under anaerobic conditions or allochthonous input to anoxic hot spots. This would require reconsidering the current conceptual functioning of riparian buffer zones.

\section{Abbreviations}

DOC, dissolved organic carbon; GCM, general circulation model; POC, particulate organic carbon.

\section{Competing interests}

The authors declare that they have no competing interests.

\section{References}

I. Hannah DM, Sadler JP, Wood PJ: Hydroecology and ecohydrology: a potential route forward? Hydrol Process 2007, 2 I:3385-90.

2. Wilby RL, Whitehead PG, Wade AJ, Butterfield D, Davis RJ, Watts G: Integrated modelling of climate change impacts on water resources and quality in a lowland catchment: River Kennet, UK. J Hydrol 2006, 330:204-20.

3. Frei C, Schöl R, Fukutome S, Schmidli J, Vidale PL: Future change of precipitation extremes in Europe: an intercomparison of scenarios from regional climate models. J Geophys Res 2006 , I I I:D06105

4. Galloway JM: The global nitrogen cycle: changes and consequences. Environ Pollut 1998, 102:15-24. 
5. Huntington TG: Evidence for intensification of the global water cycle: review and synthesis. J Hydrol 2006, 31 9:83-95.

6. Hynes HB: The stream and its valley. Verh Internat Verein Theor Angew Limnol 1975, 19:1-I5.

7. Vannote RL, Minshall GW, Cummins KW, Sedell JR, Cushing CE: The river continuum concept. Can J Fish Aquat Sci 1980, 37:130-7.

8. Newbold JD, O'Neill RV, Elwood JW, Van Winkle W: Nutrient spiraling in streams: implications for nutrient limitation and invertebrate activity. Am Nat 1982, 120:628-52.

9. Peterjohn WT, Correll DL: Nutrient dynamics in an agricultural watershed: observations on the role of a riparian forest. Ecology 1984, 65: 1466-75.

10. Rivett MO, Buss SR, Morgan P, Smith JW, Bemment CD: Nitrate attenuation in groundwater: a review of biogeochemical controlling processes. Water Res 2008, 42:4215-32.

II. McClain ME, Boyer EW, Dent CL, Gergel SE, Grimm NB, Groffman PM, Hart SC, Harvey JW, Johnston CA, Emilio Mayorga E, McDowell WH, Pinay G: Biogeochemical hot spots and hot moments at the interface of terrestrial and aquatic ecosystems. Ecosystems 2003, 6:30I-I2.

12. Sabater S, Butturini A, Clement IC, Burt TP, Dowrick D, Hefting M, Maître V, Pinay G, Postolache C, Rzepecki M, Sabater F: Nitrogen removal by riparian buffers under various $\mathbf{N}$ loads along a European climatic gradient: patterns and factors of variation. Ecosystems 2003, 6:20-30

13. Hefting MM, Bobbink R, de Caluwe H: Nitrous oxide emission and denitrification in chronically nitrate-loaded riparian buffer zones. J Environ Qual 2003, 32:1194-203.

14. Montreuil $O$, Merot $P$ : Nitrogen removal in valley bottom wetlands: assessment in headwater catchments distributed throughout a large basin. J Environ Qual 2006, 35:2II3-22.

FI000 Factor 3.0 Recommended

Evaluated by Giles Pinay 16 Sep 2008

15. Mulholland PJ, Helton AM, Poole GC, Hall RO, Hamilton SK, Peterson BJ, Tank JL, Ashkenas LR, Cooper LW, Dahm CN, Dodds WK, Findlay SE, Gregory SV, Grimm NB, Johnson SL, McDowell WH, Meyer JL, Valett HM, Webster JR, Arango CP, Beaulieu IJ, Bernot MJ, Burgin AJ, Crenshaw CL, Johnson LT, Niederlehner BR, O'Brien JM, Potter JD, Sheibley RW, Sobota DJ et al.: Stream denitrification across biomes and its response to anthropogenic nitrate loading. Nature 2008, 452:202-5.

FI000 Factor 9.0 Exceptional

Evaluated by Ingrid Bruke 27 Mar 2009

16. Brookshire ENJ, Valett HM, Gerber S: Maintenance of terrestrial nutrient loss signatures during in-stream transport. Ecology 2009, 90:293-9.

17. Bower D, Hannah DM, McGregor GR: Techniques for assessing the climatic sensitivity of river flow regimes. Hydrol Process 2004, 18:2515-43.

18. Oudin L, Andreassian V, Lerat J, Michel C: Has land cover a significant impact on mean annual streamflow? An international assessment using 1508 catchments. J Hydrol 2008, 357:303-16.

19. Merz R, Bloschl G: A regional analysis of event runoff coefficients with respect to climate and catchment characteristics in Austria. Water Resour Res 2009, 45:W0I 405.

20. Bloschl G, Ardoin-Bardin S, Bonell M, Dorninger M, Goodrich D, Gutknecht D, Matamoros D, Merz B, Shand P, Szolgay J: At what scales do climate variability and land cover change impact on flooding and low flows? Hydrol Process 2007, 2 1: | $24 \mid-7$.

21. Monteith DT, Stoddard JL, Evans CD, de Wit HA, Forsius M, Hogasen T, Wilander A, Skjelkvale BL, Jeffries DS, Vuorenmaa J, Keller B, Kopacek J, Vesely J: Dissolved organic carbon trends resulting from changes in atmospheric deposition chemistry. Nature 2007, 450:537-40.

FI000 Factor 3.0 Recommended

Evaluated by Giles Pinay 03 Mar 2008

22. Guo L, Macdonald RW: Source and transport of terrigenous organic matter in the upper Yukon River: evidence from isotope $(\delta / 3 C, \Delta I 4 C$, and $\delta I 5 N)$ composition of dissolved, colloidal and particulate phases. Global Biogeochem Cycles 2006, 20:GB20II.

23. Evans CD, Freeman C, Billett MF, Garnett MH, Norris D: Evidence against recent climate-induced destabilization of soil carbon from I4C analysis of riverine dissolved organic matter. Geophys Res Lett 2007, 34:L07407.

24. McGroddy ME, Baisden WT, Hedin LO: Stochiometry of hydrological C,N and $\mathbf{P}$ losses across climate and geology: an environmental matrix approach across New Zealand primary forests. Global Biogeochem Cycles 2008, 22:GB3005.

25. Lane SN, Reid SC, Tayefi V, Yu D, Hardy RJ: Reconceptualising coarse sediment problems in river catchments as catchmentscale and diffuse. Geomorphology 2008, 98:227-49.

26. Groffman PM, Bain DJ, Band LE, Belt KT, Brush GS, Grove JM, Pouyat RV, Yesilonis IC, Zipperer WC: Down by the riverside: urban riparian ecology. Front Ecol Environ 2003, 6:315-2I.

27. Triska FJ, Duff JH, Sheibley RW, Jackman AP, Avanzino RJ: DIN retention-transport through four hydrologically connected zones in a headwater catchment of the upper Mississippi River. J Am Water Resour Assoc 2007, 43:60-7I.

28. Cole JJ, Prairie YT, Caraco NF, McDowell WH, Tranvik LJ, Striegl RG, Duarte CM, Kortelainen P, Downing JA, Middelburg JJ, Melack J: Plumbing the global carbon cycle: integrating inland waters into the terrestrial carbon budget. Ecosystems 2007, 10:17|-84.

29. Gruber N, Galloway JN: An Earth-system perspective of the global nitrogen cycle. Nature 2008, 45 I:293-5.

30. Walter RC, Merritts DJ: Natural streams and the legacy of water-powered mills. Science 2008, 3 19:299-304

FI000 Factor 6.5 Must Read

Evaluated by Roland Jansson 04 Feb 2008, Curtis Richardson 06 Feb 2008, Giles Pinay 12 Mar 2008

31. Monk WA, Wood PJ, Hannah DM, Wilson DA: Macroinvertebrate community response to inter-annual and regional river flow regime dynamics. River Res Appl 2008, 24:988-100I.

32. Kundzewicz ZW, Mata LJ, Arnell NW, Doll P, Jimenez B, Miller K, Oki T, Sen Z, Shiklomanov I: The implications of projected climate change for freshwater resources and their management. Hydrol Sci J 2008, 53:3-10.

33. Peel MC, McMahon TA: A quality-controlled global runoff data set. Nature 2006, 444:EI4.

34. Prudhomme $\mathrm{C}$, Davies $\mathrm{H}$ : Assessing uncertainties in climate change impact analyses on the river flow regimes in the UK. Part I: baseline climate. Clim Change 2009, 93:177-95.

35. Wilby RL, Harris I: A framework for assessing uncertainties in climate change impacts: low-flow scenarios for the River Thames, UK. Water Resour Res 2006, 42:W024I9.

36. Sutka RL, Ostrom NE, Ostrom PH, Breznak JA, Gandhi H, Pitt AJ, Li F: Distinguishing nitrous oxide production from nitrification and denitrification on the basis of isotopomer abundances. Appl Environ Microbiol 2006, 72:638-44.

FI000 Factor 3.0 Recommended

Evaluated by Gilles Pinay 13 Mar 2008

37. Clément JC, Shrestha J, Ehrenfeld JG, Jaffé PR: Ammonium oxidation coupled to dissimilatory reduction of iron under anaerobic conditions in wetland soils. Soil Biol Biochem 2005, 37:2323-8.

FI000 Factor 3.0 Recommended

Evaluated by Gilles Pinay 21 Mar 2006 